\title{
Lakon Wahyu Cakraningrat dalam Paradigma Strukturalisme
}

\author{
ARIS WAHYUDI* \\ Jurusan Pedalangan, Fakultas Seni Pertunjukan, \\ Institut Seni Indonesia Yogyakarta
}

\begin{abstract}
Wahyu Cakraningrat Play in Structuralism Paradigm. Lakon Wahyu Cakraningrat as a cultural phenomenon is basically a means of communication between composer with readers, viewers and listeners to the puppeteer. It is created by using a symbol system in the puppet, so that in every play of puppet, it always contains the meaning which can be known and understood well by the composer, puppeteer, and the community. These rules manage the system of symbols in the phenomenon of puppet plays, in their capacity as the "grammar" puppet plays with using Levi-Strauss's structuralism paradigm. This is going to be gained the interpretation that Lakon Wahyu Cakraningrat is a work of art presenting some knowledge of Javanese culture.
\end{abstract}

Key words: cakraningrat, strukturalisme, Levi-Strauss

\section{Pendahuluan}

Lakon Wahyu Cakraningrat yang mengisahkan tentang penitisan Wahyu Cakraningrat untuk mendudukkan seseorang menjadi pancer ratu tanah Jawa merupakan salah satu fenomena budaya Jawa yang merupakan salah satu representasi pengetahuan orang Jawa yang bersumber dari mitologi yang diterima secara universal untuk menginterpretasikan dunianya, baik mikrokosmos maupun makrokosmos (Laksono, 1985: 22). Artinya bahwa Lakon Wahyu Cakraningrat tersebut merupakan salah satu sarana komunikasi melalui media seni pedalangan. Dengan demikian tentu di dalamnya terdapat sejumlah pesan untuk diacu oleh penerimanya.

Sebagai sarana komunikasi, lakon wayang memiliki "bahasa" dan kode serta kaidah-kaidah tersendiri yang telah dipahami dan dimengerti, baik oleh dalang maupun penerimanya karena lakon wayang memiliki ketertataan dan keterulangan. Kaidah-kaidah tersebut oleh LéviStrauss disebut deep structure, yaitu struktur yang tidak tampak, tidak disadari oleh penggunanya, namun bisa diidentifikasi dan dapat diabstraksikan dalam beberapa fenomena budaya sehari-hari
(Ahimsa-Putra, 2006: 61). Artinya dengan memahami struktur Lakon Wahyu Cakraningrat ini dapat digunakan untuk mempelajari beberapa fenomena budaya yang lain, yang dijumpai dalam kehidupan sehari-hari. Yang menjadi pertanyaan adalah: "Bagaimanakan Struktur Lakon Wahyu Cakraningrat?"

Menurut Lévi-Strauss, dapat dikaji melalui analisis strukturalisme. Dalam pandangan ini bahwa setiap fenomena budaya dipandang sebagai sebuah mitos, yang memiliki struktur luar (surface structure) dan struktur dalam (deep structuire). Struktur luar adalah struktur yang dibangun atas relasi antar unsur dalam tataran fakta-fakta empiris; sedangkan struktur dalam adalah struktur yang dibangun atas relasi antar relasi yang diperoleh dari analisis struktur luar. Dari deep structure inilah nantinya akan diperoleh makna yang tersembunyi di balik apa yang tampak, apa yang terceritakan atau "hidden meanings".

Lakon wayang sebagai mitos di sini dipandang sebagai sebuah teks yang dalam analisisnya dapat disejajarkan dengan kalimat (Ahimsa-Putra, 1998: 19; Ahimsa-Putra, 2006: 80; Lévi-Strauss, 1967: 206). Namun demikian, diingat oleh Lévi-

\footnotetext{
* Alamat korespondensi: Jln. Parangtritis KM. 6,5 Yogyakarta Tlp. 0274-375380. e-mail: arisdalang@yahoo.com
} 
Strauss bahwa mitos berada pada level yang lebih atas dan kompleks daripada level kebahasaannya. Oleh karena itu, dalam analisisnya tidak hanya sebatas pada fenomena kebahasaan saja (LéviStrauss, 1967: 206 - 207). Yang artinya, dalam rangka memaknai sebuah lakon wayang tidak cukup menafsirkan apa yang terceritakan (struktur luar) saja tetapi mencari apa yang tidak dikatakan atau yang ada di balik yang terceritakan (struktur dalam) (Palmer, 1985: 171).

Lakon Wahyu Cakraningrat dalam rangka ini Sebagaimana dalam fenomena kebahasaan, dapat diuraikan lagi menjadi tingkat yang lebih kecil (seperti fonem, morfem, dan sememes dalam fenomena kebahasaan) yaitu pathêt, jêjêr, dan adegan yang menampilkan tokoh, peristiwa, dan seting yang relasi antar relasi terkecilnya (oposisi berpasangan) dipandang sebagai unsur pokok atau miteme (Lévi-Strauss, 1967: 205; Ahimsa-Putra, 2006: 94; Paz, 1997: 18).

Lakon Wahyu Cakraningrat merupakan dunia simbol yang di dalamnya mengandung penanda atau citra suara (signifier) dan tinanda atau konsep (signified). Kepenandaan dan ketinandaan ini ditentukan oleh kerangka relasionalnya dengan penanda dan tinanda yang lain. Sebagai media untuk menyampaikan pesan (sarana komunikasi), Lakon Wahyu Cakraningrat memiliki aspek langue dan parole yang berada dalam bingkai jagad pewayangan. Di dalamnya juga terdapat sisi sinkronis dan diakronis yang keduanya diberlakukan secara bersama-sama. Makna Lakon Wahyu Cakraningrat dibangun atas relasi antar unsur pokok (miteme), baik hubungan secara sintagmatik maupun paradigmatik (Ahimsa-Putra, 2006: 34-35).

Hubungan sintagmatik satu tokoh (miteme) adalah hubungan yang dimilikinya dengan tokoh-tokoh lain, permasalahan dan peristiwa, serta seting-nya (miteme yang lain), baik dalam satu adegan maupun dengan adegan yang lain dalam sebuah lakon. Hubungan sintagmatik sebuah adegan adalah hubungan yang dimilikinya dengan adegan sebelum atau sesudahnya. Dengan demikian hubungan sintagmatik adalah jalinan miteme-miteme dalam membentuk rangkaian kisah yang bermakna (Ahimsa-Putra, 2006: 47). Sebuah miteme atau adegan apabila kehilangan beberapa hubungan sintagmatiknya atau memperoleh hubungan sintagmatik baru (berbeda), ia akan berubah maknanya atau bahkan menjadi tidak bermakna (Ahimsa-Putra, 2006: 49). Hubungan paradigmatig sebuah simbol (miteme) adalah hubungan-hubungan esensial yang dimilikinya, yang memisah-misahkan berbagai perbedaan dalam rangka pendefinisian simbol tersebut (Ahimsa-Putra, 2006: 49). Artinya bahwa hubungan paradigmatik dalam wayang adalah suatu asosiasi yang secara referensial telah dimiliki masyarakat pendukungnya atas sebuah simbol.

Hubungan sintagmatik dan paradigmatik ini merupakan satu kesatuan yang tidak dapat dipisah-pisahkan karena keduanya secara bersamasama membangun sebuah makna. Dengan demikian makna lakon adalah suatu pesan yang ditransformasikan melalui sistem relasi antar simbol. Transformasi atau alih rupa, salah satunya adalah hal-hal yang berkenaan dengan penandaan dari sebuah konsep atau makna (tinanda) yakni: sebuah konsep atau makna (tinanda) yang diwujudkan menjadi tokoh, peristiwa, maupun seting (penanda) merupakan proses transformasi dalam rangka membangun lakon wayang.

Pemaknaan sebuah miteme adalah menentukan makna-makna yang disajikan dalam bingkai hubungan paradigmatik dan kemudian ditentukan oleh sistem relasinya (struktur) dengan miteme lain dalam hubungan sintagmatik. Oleh karena itu, makna sebuah lakon wayang tidak ditentukan oleh satu tokoh atau satu adegan saja melainkan ditentukan oleh antar relasi masing-masing unsur pokok lakon tersebut dibangun, seperti halnya makna sebuah kalimat tidak ditentukan oleh satu fonem ataupun satu kata saja, melainkan ditentukan oleh kerangka relasional atas keseluruhan unsur pokok pembangunnya (LéviStrauss, 1967: 205). Makna sebuah tokoh apabila dipersandingkan dengan tokoh lain, peristiwa yang menyertainya, persoalan yang dihadapinya, dan tempat peristiwa itu berlangsung dalam sebuah kerangka relasional akan memunculkan makna baru yang menyembunyikan makna tokoh tersebut.

Penelitian menunjukkan bahwa persoalan yang berkenaan dengan hubungan paradigmatik dari sebuah miteme wayang tidak dapat mengabaikan analisis mitologi wayang. Dipahami dalam jagad pewayangan bahwa semua peristiwa yang dialami oleh tokoh tataran titah selalu melibatkan 
campur tangan tokoh-tokoh tataran dewa yang ditunjukkan melalui sistem simbol yang berupa inkarnasi, kepemilikan atas sesuatu, karakter, ciri-ciri fisik, sistem keturunan dan peristiwa yang dialami oleh tokoh yang bersangkutan (Alf Hiltebeitel, 1990: 35-37). Dipahami pula bahwa satu tokoh titah sangat mungkin memiliki lebih dari satu aspek kedewaan. Oleh karena itu pemaknaan aspek kedewaan pada masing-masing miteme akan ditentukan oleh sistem relasinya dengan miteme-miteme yang lain.

\section{Struktural Lakon Wahyu Cakraningrat}

Berdasarkan pembacaan atas keseluruhan teks Lakon Wahyu Cakraningrat diperoleh pemahaman bahwa dalam jejer I dijumpai beberapa persoalan yang dapat dikategorisasikan: Pertama, mengenai status dari tokoh-tokoh yang pergi tanpa pamit. Dialog Duryudana: "Sampun wènten saklebetipun dwi dasa dinten mlampah menika ingkeng putra yoga kula pengéran pati Sarja Kesuma murca tanpa taliwara. ...," menunjukkan bahwa Saroja Kusuma adalah pangeran pati yang artinya putra mahkota. Status Samba Wisnubrata sebagai putra mahkota ditunjukkan pada dialog Setyaki: "Gandhèng kowé karo aku lan kakang Udawa dipasrahi ngupaya murcané anggèr pangéran pati dhipati anom," yang menyatakan Samba sebagai pengeran pati. Meskipun status Abimanyu tidak disebutkan tetapi diketahui bahwa Abimanyu adalah putra Arjuna, bukan seorang raja.

Kedua, cara mencari tokoh yang pergi. Teks menunjukkan bahwa Saroja Kusuma dicari oleh dua rombongan prajurit yang dipimpin oleh Prabu Baladewa dan Prabu Karna. Samba Wisnubrata dicari oleh tiga orang yaitu Setyaki, Patih Udawa, dan Emban Druwajaya, sedangkan pihak Abimanyu belum atau tidak melalukan pencarian.Ketiga, tempat tujuan pencarian. Disebutkan dalam dialog bahwa dalam rangka mencari Saroja Kusuma dengan cara tepung gelang yang artinya dicari ke seluruh pelosok. Pencarian Samba adalah ke hutan Minangsraya dan Tuk Paribelis. Dari ketiga kategori tersebut terdapat oposisi berpasangan sebagai berikut.

putra mahkota - bukan putra mahkota dicari - tidak dicari

dicari orang banyak - dicari oleh tiga orang tujuan yang jelas - tanpa tujuan
Jejer II, kedatangan Saroja Kusuma di kayangan Ngukitpidikan untuk meminta bantuan Batari Durga agar dapat menjadi raja. Batari Durga menyanggupi dan mengajak pergi ke kahyangan Cakrakembang, menemui Batara Kamajaya untuk meminta wahyu karaton. Kategorisasi yang diperoleh adalah demografi, tataran kosmologi, dan jender. Oposisi berpasangan yang didapatkan sebagai berikut:

$$
\begin{aligned}
\text { marcapada } & - \text { kayangan } \\
\text { titah } & - \text { dewa } \\
\text { laki-laki } & - \text { perempuan } \\
\text { meminta bantuan } & - \text { memberi bantuan }
\end{aligned}
$$

Jejer III, dialog Kamajaya dalam adegan di kayangan Cakrakembang,: “...,Yèn sudara werdamu Wahyu Maningrat ing kana minangka kanggo pancering ratu, ora bakal mlèsèt ana ing wewengkon negara Ngamarta dhi." menunjukkan oposisi berpasangan.

$$
\begin{aligned}
\text { belum menitis - sudah menitis } \\
\text { dewa - wahyu } \\
\text { wahyu - titah }
\end{aligned}
$$

Kedatangan Saroja Kusuma bersama Durga di kayangan Cakrakembang menghasilkan oposisi berpasangan yang baru. Meskipun Saroja Kusuma tidak terlibat secara langsung dalam oposisi tersebut, semuayang terjadiuntuk kepentingannya, sehingga dipandang bahwa oposisi yang terjadi disebabkan oleh Saroja Kusuma. Oposisi baru tersebut adalah:

$$
\begin{aligned}
\text { dewa perempuan } & - \text { dewa laki-laki } \\
\text { dewa } & - \text { wahyu } \\
\text { mengejar } & - \text { dikejar }
\end{aligned}
$$

dan merubah komposisi oposisi: wahyu - titah menjadi titah-wahyu.

Kegagalan Batari Durga merebut wahyu dan menyuruh Saroja Kusuma turun ke marcapada membalik posisi oposisi berpasangan pada jejer II: marcapada - kayangan menjadi kayangan - marcapada

Jejer IV mengisahkan Abimanyu menjadi pertapa di hutan Ringinputih. Dalam adegan ini oposisi berpasangan yang muncul adalah:

$$
\begin{aligned}
\text { satria } & \text { - brahmana } \\
\text { kota } & \text { - hutan } \\
\text { rendah } & \text { - tinggi } \\
\text { abdi } & - \text { tuan }
\end{aligned}
$$


Ganggunan yang dijumpai dalam perjalanan Abimanyu ketika menuju Ringinputih terdapat oposisi berpasangan:

$$
\begin{aligned}
\text { raksasa } & - \text { brahmana } \\
\text { perempuan } & - \text { laki-laki } \\
\text { kasar } & - \text { halus } \\
\text { bawah } & - \text { atas }
\end{aligned}
$$

Oposisi berpasangan yang dimunculkan peristiwa Samba di hutan Minangsraya dalam jejer VI adalah:

$$
\begin{aligned}
\text { kraton } & \text { - hutan } \\
\text { rendah } & - \text { tinggi } \\
\text { berkumpul } & \text { - sendiri } \\
\text { takut } & \text { - berani } \\
\text { ramai } & \text { - sepi }
\end{aligned}
$$

Kedatangan Baladewa beserta Kurawa memunculkan oposisi berpasangan:

$$
\begin{aligned}
\text { kemenakan } & - \text { paman } \\
\text { muda } & - \text { tua } \\
\text { takut } & - \text { berani } \\
\text { dikejar } & - \text { mengejar }
\end{aligned}
$$

di dalam jurang - di atas jurang

Batara Srigati menemui Samba di dalam jurang memunculkan oposisi berpasangan:

$$
\begin{array}{r}
\text { adik - kakak } \\
\text { titah }- \text { dewa } \\
\text { bawah }- \text { atas }
\end{array}
$$$$
\text { meminta tolong - memberi pertolongan }
$$

Setelah ditolong Batara Srigati dan Samba menyatakan keinginannya, kemudian menemui Wahyu Cakraningrat untuk menitis ke Samba. Wahyu Cakraningrat bersedia dengan berbagai persyaratan. Di sini muncul oposisi berpasangan:

$$
\begin{aligned}
& \text { dewa } \text { - wahyu } \\
& \text { wahyu } \text { - titah } \\
& \text { penitis } \text { - tinitis } \\
& \text { atas - bawah } \\
& \text { ingin - tidak ingin }
\end{aligned}
$$

Dalam perjalanan, Samba bertemu Saroja Kusuma. Sesuai dengan pesan Batari Durga, Saroja Kusuma akan membunuh Samba. Karena Samba telah mendapatkan Wahyu, usaha Saroja Kusuma gagal. Dikisahkan Samba terlalu sombong sehingga dianggap sebagai tempat penitisan yang tidak layak, dan Wahyu Cakraningrat meninggalkannya. Oposisi berpasangan yang muncul adalah:

$$
\begin{aligned}
\text { layak } & \text { - tidak layak } \\
\text { menitis } & - \text { oncat }
\end{aligned}
$$

Kemudian Wahyu Cakraningrat menitis ke Saroja Kusuma. Kasusnya sama dengan Samba, demikian juga oposisi berpasangan yang muncul. Mereka berdua mengejar Wahyu Cakraningrat.

Cerita beralih ke Abimanyu yang sedang tapa mbisu di bawah pohon beringin putih (Jejer VI). Ketika Wahyu Cakraningrat datang dan melihat teja Wahyu Maningrat, segera menyusul menitis ke Abimanyu. Di sini muncul oposisi berpasangan dalam tataran demografi, kosmologi, dan ritual.

$$
\begin{array}{r}
\text { tepi }- \text { tengah } \\
\text { bawah }- \text { atas } \\
\text { wahyu - titah } \\
\text { penitis - tinitis }
\end{array}
$$

Sesaat kemudian Saroja Kusuma dan Samba datang untuk merebut Wahyu. Dengan kerendahan hati, Abimanyu berhasil mengalahkannya. Oposisi berpasangan atas ketiga tokoh ini dari jejer I dipertemukan, yaitu:

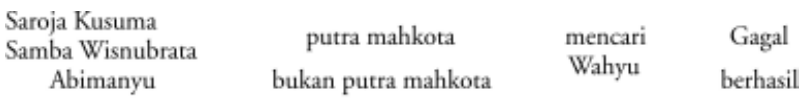

Teks menunjukkan bahwa proses yang ditempuh Saroja Kusuma dalam mendapatkan wahyu terdapat dalam jejer II, III, dan V; Pencarian wahyu yang dilakukan Samba terdapat dalam jejer $V$; sedangkan yang ditempuh Abimanyu terdapat dalam jejer $I V$ dan $V I$. Dari peristiwa ketiga tokoh tersebut secara sintagmatik dapat disusun sebagai berikut.

* Saroja Kusuma: dibantu Durga - Durga perang melawan Kamajaya - mengejar Wahyu - turun ke marcapada-wahyu menitis dengan syarat - tidak layak - wahyu oncat.

* Samba: meditasi di hutan Minangsraya dikejar Kurawa - nyemplung jurang - ditolong Srigati - wahyu menitis dengan syarat - tidak layak - wahyu oncat.

* Abimanyu: menjadi brahmana di hutan Ringinputih - mengatasi godaan Malingsukma dan Malingraga - naik te tengah hutan - tapa mbisu di bawah pohon beringin putih - wahyu menitis tanpa syarat - layak.

Dari rangkaian ketiga peristiwa tersebut diperoleh oposisi berpasangan berikut.

Ke kayangan - ke hutan Bertapa - tidak bertapa dibantu - ridak dibantu 
mampu mengatasi - tidak mampu mengatasi rintangan rintangan naik - turun tepi - tengah layak - tidak layak menetap - oncat

oposisi berpasangan tersebut dapat disusun dalam tabel berikut.

\begin{tabular}{|c|c|c|c|c|c|c|c|}
\hline SK & \multirow[b]{2}{*}{$\begin{array}{l}\text { Mencari } \\
\text { wahyu }\end{array}$} & kayangan & \multirow{2}{*}{$\begin{array}{l}\text { Tidak } \\
\text { bertapa }\end{array}$} & \multirow[b]{2}{*}{ dibantu } & \multirow{2}{*}{$\begin{array}{c}\text { Tidak } \\
\text { mampu } \\
\text { mengatasi } \\
\text { rintangan } \\
\end{array}$} & \multirow[b]{2}{*}{ turun } & \multirow{2}{*}{$\begin{array}{l}\text { Tidak } \\
\text { layak }\end{array}$} \\
\hline SW & & hutan & & & & & \\
\hline$\overline{A B}$ & & & bertapa & tidak & mampu & naik & layak \\
\hline
\end{tabular}

Tabel 1. Oposisi berpasangan sweba (sw), sarja kusuma (sk) dan abimanyu $(\mathrm{ab})$

Tabel 1 belum menunjukkan struktur lakon. Keberhasilan Abimanyu dalam rangka mendapatkan Wahyu Cakraningrat tentunya tidak sematamata karena dia bukan putra mahkota, atau sebaliknya kegagalan Saroja Kusuma dan Samba bukan karena statusnya sebagai putra mahkota melainkan atas dasar relasi oposisi berpasangan yang lainnya. Untuk menafsirkannya perlu menyusun miteme-miteme yang menghasilkan oposisi berpasangan tersebut dalam tabel relasi sintagmatik (horisontal) dan relasi paradigmatik dalam kolom (vertikal). "Kayangan, tidak bertapa, dibantu, tidak dapat mengatasi rintangan, turun, dan tidak layak" merupakan oposisi berpasangan yang muncul dari miteme: Saroja Kusuma pergi ke Ngukirpidikan untuk meminta bantuan Durga agar mendapatkan wahyu. Kamajaya mengatur penitisan wahyu. Durga minta wahyu, tidak diberikan. Durga mengalahkan Kamajaya. Durga mengejar Wahyu dan gagal menangkap. Saroja Kusuma disuruh turun ke marcapada untuk membunuh seorang pertapa dengan menggunakan keris. Saroja Kusuma mendapatkan wahyu tetapi tidak mampu memenuhi syarat yang diminta wahyu. Dianggap tidak layak dan wahyu oncat. Oposisi "hutan, tidak bertapa, dibantu, tidak mampu mengatasi rintangan, turun, dan tidak layak" pada kisah Samba muncul dari miteme: Samba meditasi di hutan Minangsraya, dikejar Kurawa lantas nyemplung jurang untuk menyelamatkan diri, dibantu Srigati untuk mendapatkan wahyu. Wahyu menitis dengan syarat, orang yang tidak mampu melaksanakan syarat wahyu, wahyu akan oncat. Oposisi berpasangan pada Abimanyu muncul dari miteme: menjadi brahmana di hutan Ringinputih, dalam perjalanannya ke tengah hutan, mengalahkan
Malingraga dan Malingsukma, tapa mbisu di bawah pohon beringin putih, wahyu menitis tanpa syarat. Miteme-miteme ini disusun dalam tabel untuk ditafsirkan maknanya

Berdasarkan relasisintagmatikdan paradigmatik menunjukkan bahwa kegagalan Saroja Kusuma dalam mendapatkan wahyu karena kegagalannya mengatasi oposisi-oposisi yang dihadapinya. Oposisi yang terceritakan ditunjukkan ketika dia tidak berhasil memenuhi pesan Wahyu Cakraningrat sehingga wahyu oncat. Oposisi yang tidak terceritakan juga dapat ditemukan. Pada perjalanan Saroja Kusuma dalam jejer II meunjukkan adanya oposisi berpasangan dalam tataran mitologi. Saroja Kusuma adalah nama lain dari bunga teratai. Dipahami dalam tradisi wayang bahwa Batari Durga berdiri beralaskan bunga teratai. Fenomena demikian juga dijumpai dalam arca Durga di candi Prambanan. Artinya bahwa oposisi berpasangan di sini adalah:

$$
\begin{aligned}
& \text { atas - bawah } \\
& \text { titah - dewa }
\end{aligned}
$$

Komunikasi antara tataran titah dengan tataran dewa dapat dipandang sebagai sebuah ritual. Pertemuan tersebut terjadi tanpa menunjukkan proses atau laku tertentu. Artinya, di sini mengindikasikan bahwa proses ritual Saroja Kusuma adalah memuja Durga.

Teks menunjukkan adanya relasi kekeluargaan antara Durga dengan Saroja Kusuma sebagai nenek dan cucu kesayangan. Relasi demikian akan semakin tampak dengan melihat Duryudana dalam kapasitasnya sebagai titisan Batara Kali yang memiliki kesejajaran dengan Durga sebagai Batari Kali. Dengan demikian oposisi yang muncul adalah sebagai berikut.

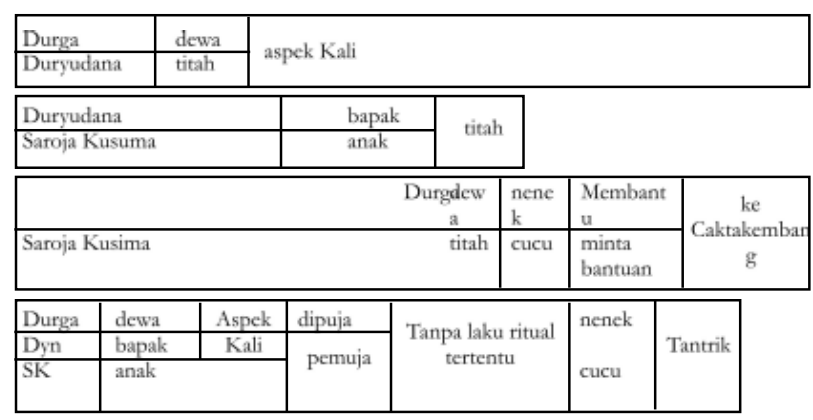

Tabel 2. Oposisi berpasangan Durga, Duryudana, dan Saroja Kusuma.

Oposisi berpasangan yang melibatkan relasinya dengan Duryudana menegaskan kualitas relasi Saroja Kusuma - Durga. Relasi dari relasi oposisi 
berpasangan yang ada dalam perjalanan Saroja Kusuma dalam mendapatkan wahyu dengan relasi oposisi Duryudana - Durga menunjukkan bahwa laku yang dijalankan Saroja Kusuma dalam Lakon Wahyu Cakraningrat ini mengikuti ajaran dalam tataran ritual Tantrik (Sanjukta Gupta, 1979: 17). Artinya bahwa Saroja Kusuma mampu mengatasi oposisi berpasangan dalam tataran mitologi:

$$
\begin{aligned}
\text { marcapada } & - \text { kayangan } \\
\text { titah } & - \text { dewa } \\
\text { bawah } & - \text { atas }
\end{aligned}
$$

Tantrisme yang dijalankan Saroja Kusuma tersebut mengakibatkan ketidakmampuannya dalam mengatasi oposisi berpasangan Durga - Kamajaya dalam tataran ritual (jejer III). Sebagaimana dipahami bahwa Kamajaya adalah dewa Kama. Dewa Kama diidentikkan dengan dewa Brahma karena pada dasarnya kedua dewa tersebut merupakan satu prototipe dewa pencipta. Identifikasi tersebut didasarkan pada kapasitas Kama sebagai penguasa sperma dan asmara yang menjadi bagian utama bagi lahirnya makhluk baru di dunia. Kapasitas demikian diakui kebenarannya sehingga Brahma-Wisnu-Syiwa disebut juga Kama-Wisnu-Syiwa. Dipahami bahwa Brahma adalah isthasewata dalam tataran Wedik (Gonda, 1989: 4). Dengan demikian dalam jejer III terdapat oposisi berpasangan atas dua Isthadewata yaitu Durga dalam Tantrik dan Brahma dalam Wedik.

Tantrisme - Widikisme

Dengan membiarkan Durga mengalahkan Kamajaya menunjukkan bahwa Saroja Kusuma mempertahankan Tantrismenya. Artinya Saroja Kusuma tidak mampu mengatasi oposisi berpasangan dalam tataran ritual yang muncul dalam jejer III. Teks janturan "Ingkeng kepareng lenggah wèntening kayangan Cakrakembang: sang Hyang Kumajaya, satunggalingjawata ingkangtinanggenah angatur tumuruning wahyu-wahyu kraton," menunjukkan bahwa Kamajayalah yang berkuasa mengatur turunnya Wahyu Cakraningrat. Dengan dia berpihak pada Durga, berarti dia memisahkan kedudukan Durga dan Kamajaya dalam tataran dewa. Di sinilah kunci kegagalan Saroja Kusuma dalam mendapatkan Wahyu Cakraningrat.

Kegagalan Samba Wisnubrata dalam mendapatkan wahyu Cakranegara karena tidak mampu mengatasi oposisi-oposisi yang dihadapinya. Rasa berani dan ketakutan berkecamuk dalam dirinya yang membuat meditasinya tidak sempurna. Ia juga tidak dapat mengatasi oposisi paman - kemenakan. Hal ini juga memiliki relasi ketidakmampuannya mengatasi oposisi berpasangan takut - berani. Keragu-raguan menghantui pikirannya sehingga tidak berani menyatakan tujuannya kepada Baladewa. Ketidakmampauan ini juga mengakibatkan dia masuk jurang. Karena meditasinya tidak berhasil, Samba tidak menunjukkan Isthadewata-nya. Artinya Samba tidak mampu memasuki tataran ritual sehingga dia tidak dapat menyatukan Srigati dan Kamajaya dalam tataran dewa bahkan tidak mempertemukan. Dengan kualitas spiritual yang demikian maka wajar apabila Samba tidak mendapat Wahyu Cakraningrat.

Keberhasilan Abimanyu mengatasi hambatan karena keberhasilannya dalam mengatasi oposisioposisi yang dijumpainya, sejak pertama. Nama Madubranta berarti kumbang yang dapat dimaknai sebagai pertapa yang tekun dan selalu melantunkan mantra-mantra. Gentur tapané serta keakrabannya dengan panakawan menunjukkan bahwa Abimanyu mampu mengatasi oposisi

\begin{tabular}{|c|c|c|}
\hline praja & - & hutan \\
\hline rendah & & tinggi \\
\hline abdi & & tuan \\
\hline serius & & clèlèkan \\
\hline ramai & & sepi \\
\hline jasmani & & rohani \\
\hline
\end{tabular}
berpasangan dalam tataran geologis, sosiologis, dan kosmologis.

Dengan keberhasilannya mengatasi oposisioposisi tersebut membuat Abimanyu mampu mengatasi oposisi berikutnya yang muncul ketika berhadapan dengan para penggodanya, Malingraga dan Malingsukma yang berubah wujud menjadi perempuan bernama Endang Prihatin dan Madusari:

$$
\begin{aligned}
\text { raga - } & \text { sukma } \\
\text { pahit }- & \text { manis. } \\
\text { buruk rupa - } & \text { cantik } \\
\text { laki-laki }- & \text { perempuan }
\end{aligned}
$$

Prihatin artinya sedih, menderita, kekurangan, pahit, sedangkan madusari berasal dari kata madu dan sari (inti), dapat dimaknai sebagai sesuau yang menyenangkan. Dengan demikian Abimanyu telah mampu mengatasi pahit getirnya jiwa-raga. Demikian juga oposisi-oposisi berpasangan selanjutnya selalu dapat diatasinya. Seluruh peristiwa yang dialami Abimanyu dari 
menjadi pertapa yang gentur tapane sampai tapa mbisu menunjukkan bahwa ia telah menjalankan pravretti yang meliputi sesaji, mantra dan laku dalam ritual Wedik (Anonim, 1982: 58). Telah disebutkan di atas bahwa Isthadewata dalam tataran Wedik adalah Brahma. Artinya bahwa di sini Abimanyu berkedudukan sebagai pemuja Kamajaya. Kamajaya adalah pengatur turunnya Wahyu Cakraningrat. Artinya bahwa Abimanyu berhasil mengatasi oposisi berpasangan pada tataran mitologis.

Dari relasi-relasi oposisi berpasangan yang dihadapi ketiga tokoh di atas, masing-masing membentuk struktur yang berbeda.

1. struktur cerita Saroja Kusuma adalah:

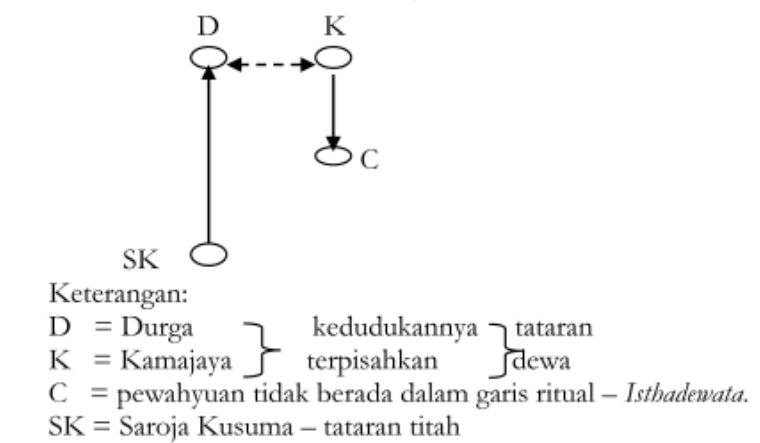

2. struktur cerita Samba Wisnubrata adalah:

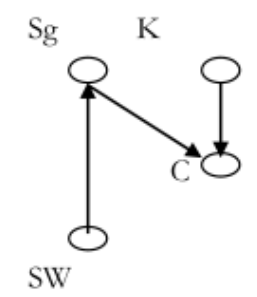

Keterangan:

$\mathrm{Sg}=$ Srigati $\}$ tataran $\}^{\text {tidak }}$

$\mathrm{K}=$ Kamajaya $\}$ dewa $\}$ dipertemukan

$\mathrm{C}$ = pewahyuan tidak berada dalam garis ritual - Isthadeneata. $\mathrm{SW}=\mathrm{Samba}$ Wisnubrata - tataran titah.

3. struktur cerita Abimanyu adalah:

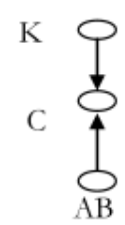

Keterangan:

$\mathrm{K}$ = Kamajaya

$\mathrm{C}$ = Pewahyuan berada dalam satu garis ritual - Isthadewata. $\mathrm{AB}=$ Abimanyu

Dari ketiga pola di atas tampak bahwa yang berhasil mendapatkan Wahyu adalah pola yang ke tiga, struktur Abimanyu yang menyatukan tataran dewa dan tataran titah berada dalam satu garis ritual. Dengan demikian struktur Lakon Wahyu Cakraningrat adalah struktur tiga tegak.

\section{Struktur dalam Konteks Budaya Jawa}

Struktur tiga tegak tersebit di atas dapat dijumpai dalam pembagian tataran kosmologi Jawa. Menurut pemahaman masyarakat Jawa bahwa alam semesta ini terdiri dari tiga tataran, yaitu: alam niskala sebagai alam di atas alam manusia, alam sakala merupakan alam manusia, dan alam sakala-niskala merupakan alam mediator untuk pertemuan antara alam manusia dengan alam atas atau alam sakala dengan alam niskala, yang strukturnya adalah sebagai berikut.

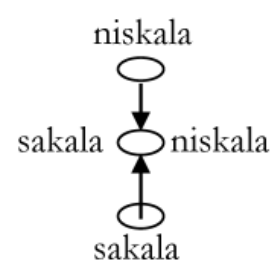

Artinya bahwa rangkaian elemen di atas pada dasarnya terdiri dari tiga unsur: permasalahan - cara menyelesaikan masalah - hasil dari penyelesaian masalah. Struktur tiga tersebut mirip dengan konsep purwa - madya - wasana dalam laku Jawa, yang strukturnya sebagai berikut.

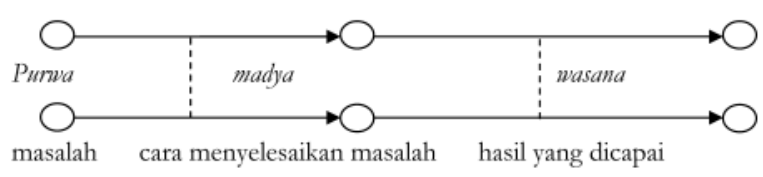

Yangterjadidalammadyadancaramenyelesaikan masalah tergantung atau menyesuaikan dengan purwa dan permasalahannya. Madya dan cara menyelesaikan masalah sangat menentukan wasana dan keberhasilannya.

Struktur tiga juga dijumpai dalam konsepkekuasaan Jawa. Bagi masyarakat Jawa, raja merupakan simbol kesempurnaan. Keberadaan dan keagungannya diakui dengan ikhlas oleh rakyatnya berdasarkan peranannya sebagai wakil Tuhan untuk mengayomi, mengatur tata kehidupan di bumi. Mengingat kapasitas raja yang demikian, maka seorang raja harus mampu menciptakan suasana manunggaling kawula Gusti yaitu hubungan yang harmonis seperti layaknya ikatan keluarga, baik antara penguasa dengan rakyat maupun antara rakyat dengan rakyat. 
Raja dalam memutuskan kebijakan harus selalu memperhatikan kepentingan rakyat seperti seorang ayah yang mengasuh anaknya (Moertono, 1985: 17). Dengan demikian seluruh warga negara saling menghargai dan menghormati. Mereka melaksanakan semua hak dan kewajiban dengan perasaan ikhlas sesuai dengan kapasitas masing-masing berdasarkan takdir (Moertono, 1985: 19). Terciptanya kondisi demikian akan mewujudkan suasana negara yang tenteram dan damai. Untuk mencapai tujuan tersebut, seorang raja harus mendapatkan wahyu kraton. Disamping itu, raja harus memiliki kesempurnaan lahir dan batin karena kecacatan raja dianggap pula sebagai kecacatan Negara (Moertono, 1985: 47). Untuk mencapainya, seorang raja harus mendapatkan wahyu kraton dan berasal dari dinasti yang agung. Dengan demikian dapat dikatakan bahwa keidealan kualitas spiritual dan jasmani seorang raja dibentuk oleh wahyu kraton dan keagungan dinastinya, dan berkahnya akan mengalir keseluruh rakyatnya. Oleh karena peran wahyu sangat besar dalam menentukan sistem kekuasaan, maka sistem kerajaan pun juda bersifat reinkarnatif. Meskipun raja masih hidup, wahyu itu bisa pindah atau bersifat reinkarnatifkan kepada orang lain (Ong Hok Ham, 1985: 8). Sebagaimana dalam pepatah Jawa: "sapa sing duraka, wahyuné bakal sirna"

Dengan demikian konsep raja Jawa terdiri dari tiga elemen dasar: (1) raja ideal, (2) wahyu kraton, (3) keagungan dinasti. Sistem relasinya adalah raja ideal ditentukan oleh wahyu dan keagungan dinasti. Dipilihnya Abimanyu merupakan upaya orang Jawa untuk memposisikan raja sebagai keturunan dinasti yang agung, yang dikaitkan dengan Arjuna. Dalam tradisi wayang Ngayogyakarta, Arjuna memiliki kualitas heroik, kualitas ksatria terhormat, yang digunakan untuk mengidentifikasi para raja dan pemimpinnya (Atmaja, 2006: 173). Oleh karena itu Arjuna memiliki posisi kunci dalam sstem kekuasaan Jawa.

Struktur demikian juga digunakan dalam masyarakat awam terutama dalam konsep kekerabatan (memilih menantu) yang diistilahkan bobot, bibit, bêbêt. Bobot adalah kualitas seseorang; bibit adalah dari keturunan siapa; dan bêbet berorientasi pada status sosial. Relasi tiga unsur tersebut adalah bêbêt (status sosial) ditentukan oleh kualitas (bobot) dan keturunan (bibit). Kemiripan tersebut digambarkan pada relasi struktur tiga berikut.

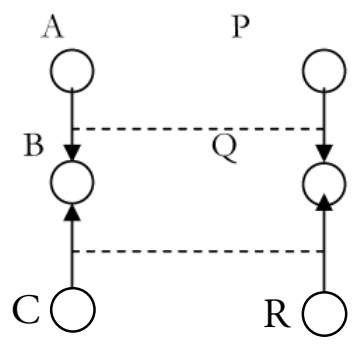

Keterangan:

$$
\begin{array}{ll}
\mathrm{A}=\text { wahyu kraton. } & \mathrm{P}=\text { bobot. } \\
\mathrm{B}=\text { raja ideal } & \mathrm{Q}=\text { bêbêt. } \\
\mathrm{C}=\text { dinasti } & \mathrm{R}=\text { bibit. }
\end{array}
$$

Berkenaan dengan wahyu kraton, dalam tradisi pedalangan Ngayogyakarta pahami bahwa wahyu kraton yang menitis ke dalam Abimanyu ada tiga yaitu Wahyu Maningrat, Wahyu Cakraningrat, dan Wahyu Widayat. Kepemilikan Abimanyu atas tiga Wahyu kraton kaitannya dengan pancer ratu tanah Jawa memiliki kemiripan dengan konsep kekuasaan kraton Ngayogyakarta (Mataram) yang juga memandang bahwa raja harus memiliki tiga wahyu kraton, yaitu wahyu nubuah, wahyu hukumah dan wahyu wilayah (Soedarsono, 1997: 123).

\section{Penutup}

Berdasarkan uraian di atas diperoleh kesimpulan bahwa melalui analisis strukturalisme diperoleh makna baru yang berada di luar apa yang terceritakan, yaitu sebuah struktur atau deep structure yang berbeda dengan struktur pertunjukan atau struktur dramatik yang dipahami secara empiris. Struktur tersebut adalah struktur tiga, merupakan kaidah yang mengatur kerangka relasional sistem simbol di dalamnya.

Kerangka relasional, baik secara sintagmatik maupun paradigmatikatassimbolyangditampilkan melalui tokoh, seting, permasalahan, dan peristiwanya merupakan representasi dari konsep ritual, yaitu sebuah laku yang menghubungkan dunia bawah dengan dunia atas sebagaimana dijumpai dalam tataran ritual kosmologi Jawa. Keberhasilannya Abimanyu mendapatkan wahyu Cakraningrat menunjukkan bahwa isthadewata 
dalam lakon ini adalah Dewa Brahma yang diwujudkan dengan Batara Kamajaya dalam tradisi wayang Ngayogyakarta.

Dengan demikian Lakon Wahyu Cakraningrat merupakan salah satu cara orang Jawa dalam menjelaskan berbagai pengetahuan tentang pembagian kosmologi Jawa yang terbagi dalam tiga tatanan.

\section{Kepustakaan}

Ahimsa Putra, Heddy Shri, 1998. "Sebagai Teks dalam Konteks Seni dalam Kajian Antropologi Budaya" dalam SENI, Jurnal Pengetahuan dan Penciptaan Seni, edisi Mei.

, 2006. Strukturalisme Lévi-Strauss, Mitos dan Karya Sastra. Yogyakarta: Kepel.

Anonim, 1982. Upadeça; Tetang Ajaran-ajaran Agama Hindu, Jakarta: Proyek Penerangan, Bimbingan dan Da’wah/Kutbah Agama Hindu dan Budha Departemen Agama RI.

Atmaja, Manu Jaya, "Parinaya sebagai Bhakti; Parinaya sebagai Durgabhakta dalam Lampahan Seta Ngraman Tradisi Wayang Yogyakarta” dalam Resital: Jurnal Ilmiah Seni Pertunjukan, Vol. 7 no. 02 - Desember 2006.

Gonda, J., 1969. Ancient Indian Kingship from the Religious Point of View, Leiden: E.J. Brill.

, 1989. Prayer and Blessing; Ancient Indian Ritual Terminology, Leiden: E. J. Brill.

Gupta, Sanjukta, et. all, 1979. Hindu Tantrism, Leiden: E.J. Brill.
Ham, Ong Hok. 1985. "Persepsi Kebudayaan Cendikiawan Indonesia" dalam Alfian (ed) Persepsi Masyarakat Tentang Kebudayaan, Jakarta: Gramedia.

Hiltebeitel, Alf. 1990. The Ritual of Battle; Krishna in The Mahabharata, Albany: State University of New York Press.

Laksono, P. M. 1985. Tradisi Dalam Struktur Masyarakat Jawa: Kerajaan dan Pedesaan Yogyakarta: Gadjah Mada University Press

Lévi-Strauss, Claude, . 1967. Structural Anthropology. Translated from The French by Claire Jacobson, New York: Anchor Books, Doubleday and Company, INC.

Moertono, Soemarsaid. 1985. Negara dan Usaha Bina-Negara di Jawa Masa Lampau: Studi tentang Masa Mataram II, abadXVI sampai XIX, Jakarta: Yayasan Obor Indonesia.

Palmer, Richard E. 2005. Hermeneutika: Teori Baru Mengenai Interpretasi, Yogyakarta: Pustaka Pelajar.

Paz, Octavio. 1997. Lévi-Strauss: Empu Antropologi Struktural, terj. Landung R. Simatupang Yogyakarta: LkiS.

Poerwadarminta, W.J.S., 1939. Baoesastra Djawa, Batavia: n.v. Groningen.

Soedarsono, R.M. 1997. Wayang Wong: Drama Tari Ritual Kenegaraan di Keraton Yogyakarta Yogyakarta: Gadjah Mada University Press.

Zoetmulder, P.J. 1994. Kalangwan: Sastra Jawa Kuno Selayang Pandang, Jakarta: Djambatan. 